\title{
Teaching Oral English in an ESL Setting: Some Challenges Observed by Teachers in Upper-West Ghana
}

\author{
Solomon A. Dansieh ${ }^{1}$ \\ ${ }^{1}$ Department of General and Liberal Studies, Wa Polytechnic, Wa Upper West Region, Ghana \\ Correspondence: Solomon A. Dansieh, Department of General and Liberal Studies, Wa Polytechnic, Wa Upper \\ West Region, Ghana. E-mail: sdansieh@yahoo.com
}

Received: April 14, 2018 Accepted: May 21, 2018 Online Published: August 22, 2018

doi:10.5539/ijel.v8n6p172 URL: https://doi.org/10.5539/ijel.v8n6p172

\begin{abstract}
This study sought to establish from teachers of English in Senior High Schools in the Upper-West Region of Ghana what they considered to be the main challenges confronting their students in the Oral English course. Thirty-four (34) teachers participated in the survey, which used questionnaire and personal observation for data gathering. The study found that there was a high tendency for features of the L1 of students to affect their learning of L2, especially in the areas of phonemes, morphemes, words, sentences and discourse structures. This was not surprising, as English was the L2 of majority of high school students in the region. The study acknowledges the need for language teachers to understand the linguistic systems of the second language of the student and how they function and be able to differentiate between the first and second language of the learner. It further concedes that a teacher's ability to speak and understand a language is not a guarantee for attaining the requisite technical knowledge for understanding and explaining the system of the language. It was observed that the challenges of pronunciation were not limited to students but affected the teachers too. The study recommends the teaching of pronunciation at basic level in an ESL context like Ghana's and also the provision of relevant teaching and learning materials for schools as well as periodic training for subject teachers.
\end{abstract}

Keywords: Oral English, ESL, teaching and learning, L1, L2

\section{Introduction}

The envious status of English language as the dominant global medium of communication cannot be disputed. Today, not only has English become the second language of many people in the world, but it has also assumed the status of a global lingua franca (Crystal, 1990). Whether it is in education, business and commerce, science and technology, or international diplomacy, English language is second to none as a communicative tool. The ability to communicate orally, no doubt, comes with lots of advantages in various situations (Nordlund, 2004). To be able to express oneself correctly and fluently in English language provides one with the key to accessing the numerous opportunities available in socio-economic and socio-linguistic environments. Kachru observes that

Competence in English and the use of this language signify a transmutation: an added potential for material and social gain and advantages. One sees this attitude in what the symbol stands for; English is considered a symbol of modernisation, and an extra arm for success and mobility in culturally and linguistically complex and pluralistic societies.

(Kachru, 1986)

In Ghana, English is the official language: In addition to its being the main medium of instruction from the basic through tertiary level of education, it is also the language used in the law books and other official documents and communication. In the educational system, a student's academic progression is heavily dependent on their performance in Core English. To progress from junior to senior high school and from SHS to tertiary, they are required to have credit (Grade 1-6 and A1-C6 respectively) in the subject. In higher educational institutions, English serves various purposes: As an academic discipline, English is a specialized area. It is taught from undergraduate up to postgraduate levels. The subject is also taught for general and specific academic or occupational purposes. English for Academic Purposes (EAP) or Language and Communication Skills, for instance, is a familiar compulsory course for first-year students in tertiary circles in English-speaking countries 
around the world with both remedial and transitional objectives to help undergraduate students metamorphose from the use of secondary lingo to tertiary (Robinson, 1991).

In spite of the obvious advantages of students' ability to communicate orally, recent research has shown that the quality of students' speaking skills in English keeps deteriorating. Generally, it has also been observed that of late candidates have been performing poorly in the English Language. Recently, the West African Examination Council (WAEC) disclosed that candidates performed abysmally in subjects such as Mathematics and English Language in this year's West African Senior School Certificate Examination (WASSCE).The provisional results, according to statistics by WAEC, fell below that of last year. The Council said the performance score range A1 C6, with English Language recording 46.79 percent as against 54.06 percent for 2017, a 7.27 percent decline. ("The Daily Guide." July, 162018 Edition). Many reasons have been cited for this sad state of affairs in secondary and tertiary institutions across the world. Some of the major factors identified as being responsible for learners' difficulties with mastering speaking skills include:

- Inadequate classroom conditions such as large student numbers;

- lack of motivation;

- poor quality teaching;

- poor quality teaching and learning materials;

- little opportunity provided to practice speaking;

- personality factors like anxiety, timidity, and low self-confidence.

(Richards, 2015)

In this study, these general causes would be considered together with country-specific factors affecting Oral English learners. The most fundamental of the country-specific causes are multilingualism and mother-tongue interference with students' speaking skills, discussed in detail under the Literature Review section. Considering the importance of the Oral English course, it is imperative that it should be handled with all the seriousness it deserves to give Senior High School (SHS) students a firm foundation in speaking skills before they get to the tertiary level. Oral communication skills, being interpersonal, can enhance student/teacher interaction in class and student/student relations. Possessing good speaking skills can also boost students' confidence so they can contribute effectively during lessons in the classroom and when it comes to peer or group discussions. It is therefore very crucial that, in addition to improving upon their writing and reading skills in the English language, students also demonstrate a mastery of the language through effective listening, understanding and speaking; for "to be orally poor means to be unable to communicate one's mind or idea verbally to another." (American TESOL, 2015).

\subsection{Objective and Relevance of the Study}

This study was conducted with a view to examining the root causes of poor oral communication skills among senior high school (SHS) students and to suggest ways of remedying the situation. Its object has been to examine the opinions of English Language teachers' on problems militating against the teaching of the Oral English course in SHSs in the Upper West Region, and based upon the findings, propose practical interventions that would help remedy the broader issue of poor communication skills among SHS students. The relevance of this study is borne by the fact that concerns raised by the teachers may be indicative of similar factors affecting the teaching of the course nationally, and even internationally; hence, suggestions made based upon the findings of the survey could also be replicated elsewhere. As this study was limited to the teacher's perspective, it would be interesting that, in the near future, a similar research is carried out to get the student's side of the story.

\subsection{Research Questions}

To attain the above objective, the study sought views of the participants through the following two main questions:

1) What do subject teachers consider the main challenges of students in the Oral English course?

2) How can these challenges be addressed?

\section{Literature Review}

\subsection{The Oral English Syllabus and Test}

Oral English constitutes part of the Core English paper, and was introduced with the hope that it would go a long way to helping improve upon the overall performance of students (Asare, 1999). The paper had hitherto been an 
optional subject and did not count towards the final grades of Ordinary Level candidates at the General Certificate of Education Examination (GCE). The compulsoriness of the subject for all registered candidates sitting the Senior Secondary School/West Africa Senior High School Certificate Examinations (SSSCE/WASSCE) came into force in November, 1999 (GNA, 1999). The Oral English syllabus designed by the Ministry of Education prepares senior high school students in two main areas: listening and speaking. The general objectives of the syllabus are to enable students to articulate various English speech sounds correctly; listen to, understand and speak English as fluently as possible and make use of appropriate stress and intonation in their reading and speech (Ministry of Education, 2010, p. 22). The content of the syllabus looks quite rich and if seriously implemented, will enhance students' oral communicative skills; however, recent research findings point to a number of factors that make the achievement of course objectives rather difficult. These are discussed in turn in the following sections.

Ufomata (1993) finds issues with the syllabus itself and the oral test conducted for candidates. Writing earlier on the subject in Nigeria, a member-country of the West African Examinations Council, the researcher observed:

As far as Oral English is concerned, no explicit policy statements have been issued. The mode of testing is still evolving as it changes from year to year thus constituting additional burdens on schools which in the first place are ill-prepared for teaching the subject.

(Ufomata, 1995, p. 2)

In what sounds like a swipe at both the government and examining body, Ufomata further observed that the entire Oral English examination has been known to be conducted in objective tests, without perception or performance tests given. In the writer's view what seems to be the case is that while the educational authorities realise the importance of teaching Oral English in schools, they find themselves unable and/or unwilling to provide the necessary funds to support effective teaching and testing of subject. This observation aptly describes the situation in Ghana. Speaking at the $18^{\text {th }}$ Annual Delegates Conference of the Ghana Association of English Teachers (GATE) held in Wa, Upper-West Ghana on the $20^{\text {th }}$ of August, 2018, the outgoing president of the Association, Mr. Joseph Kwame Gzasimatu corroborated this observation by Ufomata. Among other grievances, he bemoaned the failure of government to collaborate effectively with subject teacher associations like GATE to enhance the teaching of the discipline. A classic example he cited was the failure of government to purchase a set of English language textbooks - the Gateway Series - designed by members of association for SHS.

\subsection{Teaching Oral Communication in English in an ESL Environment}

Richards and Ranandya posit that the success of communication is dependent on the ability to use the language properly in social interactions using the appropriate pitch, stress and intonation (Richards \& Ranandya, 2002). In the view of Nunan (1989), a successful oral communication involves comprehensively using the phonological features of the language, its stress, rhythm, intonation patterns, degree of fluency, transactional and interpersonal skills as well as appropriate turn-taking, interaction management and the ability to negotiate meaning. Brown also stresses the importance of what he terms "micro-skills" and emphasizes the importance of focusing on both the forms and functions of the language (Brown, 2007). For the communication to be effective, the pieces of language should be such that it can grab the attention of others through the effective use of micro-skills of speaking such as producing phrases in the language; orally producing differences among English phonemes and allophonic variants; producing English patterns, words in stressed and unstressed positions, rhythmic structure, using cohesive devices in utterances, and accomplishing communicative functions according to the context. Speaking skills therefore involve the ability of a speaker to use the language accurately to express meaning so as to transfer or receive knowledge and information from other persons in a communicative situation (Diep, 2017).

Taking into account all the requirements in the oral communication endeavour, the task of teaching spoken English to non-native students cannot be said to be an easy one. For instance, there is the problem of the incompatibility of English sounds and spelling. As Keli-Delataa (2007:1) observes, "English pronunciation is moving further and further away from spelling." He argues that unlike some local languages, spelling provides very little clues as to how words are spoken in English. Individual sounds in different word situations or different letters may represent the same sound. In the following words 'put'/put/, 'cut' /knt/ and 'fur'/fy:e/, for instance, the letter ' $u$ ' represents different sounds. Similarly, the letters ' $u$ ', 'ou', 'o' are realized as the same sound in the words 'bus', 'courage', and 'come'. All these go to buttress the fact that teaching English pronunciation to students from an ESL background is not an easy task and will require the teacher to make a conscious effort in helping of their students to determine how to pronounce words they see written and to be able to make right decisions on what spelling pattern the words they hear spoken should take. Though the ultimate target has often been for learners to get as close as possible to the Received Pronunciation (RP) or near-native speaker 
accent in the reading and speaking of English, several factors conspire to make the attainment of that quality a mirage. For instance, there is the knotty issue of which model should be the standard, seeing that there are numerous "Englishes" across the world. Contributing to the debate of an accepted model, Bright and McGregor (1970) posed two critical questions: 1. "Suppose we could achieve complete success in making pupils speak precisely as we wish, what should we choose to do?" and 2. "What would they choose to do?" Their questions were based on the premise that "sooner or later, all countries that use English as a first or second language develop a variety of accent." Referring to varieties spoken in different English-speaking environments, Bright and McGregor observed that the varieties have "a great many common features which are far more important than their differences; otherwise, the speakers would not find each other comprehensible." They point out that the distinctions that all educated speakers make should be what matter most and not those that merely differentiate one educated speaker from another. The British accent for instance, according the two researchers, should not be imposed on any teacher or any learner of English, because just as the British speak with the British accent, other nationalities should speak with the kind of accents available in their own countries. In view of the arguments advanced, they recommend that the model to be adopted for teaching English in any country should be the variety spoken by the highly educated in those countries. Interestingly, a critical look at their arguments would suggest that the issues of pronunciation/phonetics, stress and intonation usually emphasized when it comes to teaching Oral English do not really matter. Gimson (1990), on his part, acknowledges that teaching pronunciation may present particular difficulties and may not permit progressive treatment either since all phonetic/phonological features are potentially present from the very first lesson. He recommends that teachers deal systematically with the teaching of pronunciation, even though they may be compelled to postpone the correction of some mistakes which occur in the early stages. For the scope of this study, six of the main problems militating against the effective teaching and learning of Oral English are discussed. I must concede though that the list is by no means exhaustive.

\subsection{Multilingualism and Mother Tongue Interference}

Ghana is a multilingual country with the number of different languages spoken in the country put at over seventy-nine (79). Ethnologue (2015) lists eighty-one (81) individual languages for Ghana (with 73 being indigenous and 8 non-indigenous). Each of these languages has its own pattern of pronunciation, intonation, stress, and phonology. It is therefore not surprising that most Ghanaian students would come to school already used to particular phonetic, morpho-phonological and syntactic patterns of their mother tongues. As Latha and Ramesh (2012) observed in India, the confusion begins when the students start learning the English language with its own set of patterns and rules. This phenomenon contributes to the problems associated with teaching and learning process of English language in general, and with Orals in particular. As a result of excessive mother-tongue use, when students are assigned to perform a speaking task, they tend to think about the topic in their mother tongue, frame what they want to say in their mother tongue and then translate into English, oftentimes resulting in mistakes. It is interesting and rather ironical to observe that, though some students may read and write fairly well in the English language, they are found to be deficient when it comes to expressing themselves orally. If such a linguistic deficiency is not remedied early enough, students are likely to carry that weakness through to the tertiary level and graduate but would not be able to express themselves well when they attend job interviews. They may have the relevant practical competencies in their chosen fields, but may not get the job. If they are fortunate enough to find a job at all, they are not likely to be good team-players or be able to make valuable inputs in discussions at committee meetings because their poor oral communication skills in English are going to affect their interpersonal relations negatively.

\subsection{Lack of Motivation}

In a multilingual environment like Ghana's, to get students interested in and committed to speaking English fluently through participation in class has always been a problem. As Latha and Ramesh observed in an earlier study in India, this phenomenon results in reluctance by students to actively participate in speaking activities in class leading to inadequate practice (Latha \& Ramesh, 2012). Some learners simply keep quite in class for fear of being mocked at by friends or receiving rebuke from the teacher at the slightest slip of the tongue or wrong pronunciation.

\subsection{Inadequate Classroom Conditions}

To achieve quality in any learning situation, the conduciveness of the learning environment plays an important role. Factors such as large student numbers for instance makes it impossible for teachers to have one-on-one interaction with learners to help them get over their peculiar weaknesses. Such crowded environments provide a recipe for noise and also provides an opportunity for the tongue-tied student to sit quietly and just wait for the 
lesson to end. Pedagogical research has shown that the average communication in the classroom at a Senior High School is mostly one-way communication performed by the teacher. During a 40-minute lesson, approximately 200 utterances have been made and the teacher is responsible for 150 of them, meaning the remaining 50 have to be fought for by 20 to 30 students (Ostrowski, 2001). In the circumstances, one can be sure that only the strong and fast learners will dominate. How successfully students can participate in the communication in classroom depends on how easily they can adjust to the conditions at school and how much time they have to practice oral communication (Nordlund, 2004).

\subsection{The Unavailability of Specialist and Poor Quality Teaching}

The language proficiency of teachers in teaching the Oral English course should not be taken for granted. The teacher's skill is dependent on two factors: i) proficiency in the language and ii) knowledge of and expertise in methods and techniques of language teaching. Wellman argues that

The teaching of English as a second language is a highly specialized field. It is not simply a matter of knowing English and teaching it to non-native speaker. In order to qualify for a teacher's license, a candidate must be well versed in phonetics.

Wellman (1978)

Wilkins (1982) also observes that there are countries where the teachers themselves have been relatively poorly taught, where resources are lacking and where the education itself is relatively undeveloped. Consequently teachers are not able themselves to use language for real communication let alone teach the course effectively. Chen and Goh (2011) reported about difficulties that teachers encounter in teaching Oral English in the English as a Foreign Language (EFL) context and observed that apart from external constraints such as language class sizes and a lack of teaching resources, EFL teachers are frustrated because of their own handicap in Oral English proficiency and inadequate pedagogical knowledge. Majority of the teachers expressed desire to receive training in how to design and implement effective tasks that can motivate students' engagement in oral English activities. These concerns for teacher education are indicative of an urgent call for training programmes that would strengthen teachers' knowledge for effective Oral English instruction in the EFL context (Taylor \& Francis, 2003; Aifuwa, 2013). The current practice by the Ghana Association of Teachers of English (GATE) of inviting subject area specialists to their annual delegates' conferences to give lectures on specific areas of concern is quite commendable. Broughton et al (1980) also observe the unfortunate situation where many teachers who have no specific training in the field are assigned to teach Oral English for no other reason than that their own spoken English being "good", or perhaps because they are native English speakers. Their displeasure about that practice is registered in their argument that it is one thing being a native speaker, and another being trained to teach the course as a professional teacher of English. In a case study conducted by Aifuwa (2013) involving ten schools in the Uvwie Local Government Area of Delta State in Nigeria, the problem of teaching oral English in secondary schools was investigated. He found that unnecessary emphasis on and preference for the British accent; a lack of language laboratories in Secondary Schools in the area; the inadequate skills of the Oral English teacher; and the problem of mother tongue interference among teachers of Oral English posed challenges to the teaching of the course. Among these, the lack of language laboratories in secondary schools in the area posed constituted the greatest challenge confronting the teaching of Oral English. In a multilingual environment like Ghana's, it would not be surprising to find strikingly similar phenomena in the teaching and learning of Oral English in SHSs.

\subsection{Poor Quality Teaching and Learning Materials (TLMs)}

For effective teaching and learning of Oral English to take place, there is need for quality TLMs. The availability of a standard language laboratory for instance should not be considered as a luxury, but a necessary facility to ease the burden of the teacher. Peterson (1957) emphasizes the need to have basic laboratory equipment, noting that "they are of considerable importance in the description of language structure and language teaching." Without a language laboratory, it would be difficult for the teacher to have students appreciate what goes into the production of sounds that may not be familiar to them in their various mother tongues. Unfortunately, what obtains in most SHSs in the country is that language laboratories are non-existent. Where they exist, they are meant for the teaching and learning of French and usually not open for the Oral English lessons. Relevant textbooks and audio-visual materials on the subject are also hard to come by. When all these challenges are put together, the job of the Oral English teacher becomes a nightmare rather than one that should be enjoyed and handled with all the passion that it deserves. 


\section{Methodology}

This research adopted the descriptive survey method designed to investigate the problems militating against the effective teaching of Oral English in Senior High Schools in the Upper-West Region of Ghana. The target population of the study comprised members of the Upper-West regional chapter of the Ghana Association of Teachers of English (GATE) who were drawn from all Senior High Schools in the region. A total of thirty-four (34) teachers participated in the survey. As a means of collecting data for this study, questionnaire and personal observation were employed. Responses collected were analysed using the Statistical Package for the Social Sciences (SPSS). The analysis adopted the simple percentage approach. The teachers' responses constituted the primary data for this study and supplemented with secondary data obtained from relevant literature from books and online sources. The data are represented on tables in the Appendix.

\section{Analysis and Discussion of Findings}

\subsection{Analysis}

This survey was conducted to examine the challenges inherent in the teaching and learning of Oral English in Senior High Schools in the Upper West Region of Ghana. The discussion of the findings follows responses to the main and sub-questions that were contained in a sixteen-item questionnaire summarised in tables (See Appendix) and discussed.

\subsection{Discussion}

\section{Q.1 Gender of Respondents}

A total of 34 participants were involved in the survey, majority (26) of whom were males constituting $76.5 \%$ of the total population. There were only (8) female respondents in the survey and they represented $23.5 \%$ of the population. This trend is a reflection of the general enrolment trend in schools in the region, where in spite of interventions like the Girl-child Education Programme by the Ministry of Education, female student enrolment in schools in the Upper Wes Region is still low. The trend continues to higher levels including tertiary institutions that train teachers.

\section{Q.2 Ages of Participants}

Majority (16) representing $47 \%$ of the total population of the survey participants were aged between 31 and 35 years. Those aged between 36 years and above were 14 in number and represented $41 \%$ of the population. Only four (12\%) were aged between 26 and 30. This shows that teachers of Oral English in the region are fairly young and can go for further training to improve upon their skills. Their rather young age also implies that they are likely to be in active service for a considerable length of time. This could be both advantageous and disadvantageous because the longer the skillful ones stayed in the service the better for students, but if the ill-trained ones among them stay longer, they are going to keep teaching the wrong things with disastrous outcomes for their students.

\section{Q.3 Please indicate your last higher educational institution attended}

Majority (15) of the participants, representing $44 \%$ of the population came from the University of Education, Winneba; seven, representing $21 \%$ graduated from the University of Cape Coast; six, representing $18 \%$ were graduates from the University of Ghana; with two, representing 6\% coming from the Kwame Nkrumah University of Science and Technology (KNUST). The remaining 3\% were graduates of other Colleges of Education. The fact that majority of the respondents came from UEW and UCC, two higher educational institutions noted for their expertise in training teachers in Education was interesting, but as to whether these respondents actually studied the relevant courses there to qualify them to teach Oral English at the SHS level was another question.

\section{Q.4 What is your highest qualification?}

As regards their educational backgrounds, the study found that most of the teachers had first degrees (BA, 20 representing 59\% and BSc, 12 representing 35\%) in different fields of study. Only two (6\%) of them had Masters. This means there is still room for self-improvement by way of further education to return to teach the course better and more professionally than they are currently doing.

Q.4 What is your field of study?

The fields of study of the survey participants at the degree level included: English Language: studied by 16, representing 47\% of respondents; languages other than English: (16) also constituting 47\% (i.e. eight (8) each for 
Dagaare and other languages. Teachers who offered other non-language related courses were only 2 , and represented 6 percent of the total population.

Q.5 How long have you been teaching Oral English?

The survey participants had varied degrees of experience in teaching the Oral English course. Majority (13) representing $38 \%$ of the participants had been teaching the course at the SHS level for four to six years. Those who had taught the course for a period of one to three years followed with 12 representing $35 \%$. Seven teachers had taught the course for 11 years above and constituted $21 \%$ of the population. Only one (3\%) teacher had been teaching the course for at least three years. One participant failed to respond to this question.

Q.7 Have you had any formal training in teaching Oral English?

An interesting finding in this study is that majority (19) of the respondents, representing $56 \%$ of Oral English teachers in the Upper West region conceded that they have not had any formal training in the relevant field. Only fifteen (44\%) of them admitted to having received training in a relevant area to teach Oral English. This finding confirms Broughton et al.'s (1980) observation of the practice where many teachers who have no specific training in the field are assigned to teach Oral English for the simple reason that their spoken English is "good", or perhaps because they are native English speakers. Teaching Oral English is as technical as teaching of other subjects and must therefore be assigned to persons who have had the requisite training in Linguistics or the Teaching of English as a Second Language (TESOL).

Q.8 Which class(es) do you teach?

Another worrying but interesting finding of this study is that the majority (27), representing $79 \%$ of the participants said they teach final year (SHS 3) students. This could be a contributory factor to the poor performance of students in the Core English Paper because if majority of the respondents said they had never received any formal training to teach Oral English, it is likely that some of them could be teaching the final year students and one can only imagine what skills they have been imparting to the students. Out of the total population of participants for this survey, only seven $(21 \%)$ said they taught lower classes. That does not solve the problem either, because doing well in the final year would depend on a good foundation laid at the lower level.

Q.9 What is the number on roll of the class?

As regards class sizes, the study found that majority of the Oral English classes were quite large, as (30) representing $88 \%$ of the teachers said the number on roll in a typical Oral English class was 40 and above in their schools. Only two (6\%) of them said they had smaller class sizes ranging from 10 to 19 and from 20 to 29 respectively. One participant declined to answer this question. For effective Oral English teaching, there is need for smaller class sizes so the teacher can effectively interact with learners during lessons. Large student numbers will make it difficult for teachers to have effective one-on-one interaction with learners to help them get over their peculiar weaknesses. Such crowded environments are a recipe for noise and also provides an opportunity for the tongue-tied student to sit quietly and just wait for the lesson to end. This finding confirms the observations by earlier researchers that how successfully students participate in the communication in classroom is dependent on how easily they can adjust to the conditions at school and how much time they have to practice oral communication (Ostrowski, 2001; Nordlund, 2004).

\section{Q.10 Does any of your students have English as their L1 (mother tongue)?}

As far as the linguistic backgrounds of students were concerned, only two $(6 \%)$ of the participating teachers said they had learners in their class whose mother-tongue (L1) was English. The vast majority (32) representing $94 \%$ of total number of survey participants said they had none. Though not surprising, this finding helps to affirm the fact that English is the L2 of most Ghanaian students. This has very crucial implications for the teaching Oral English as the literature has shown that teaching such a group can be challenging owing to multilingualism and other socio-linguistic factors that can directly influence their learning of a second language. This finding presupposes that the phenomena Latha and Ramesh (2012) observed in highly multilingual India could have implications for Ghanaian students too. They noted that in a multilingual environment, the confusion begins when students start learning the English language with its own set of patterns and rules. This phenomenon contributes to the problems associated with teaching and learning process of English language in general, and with Orals in particular. Excessive mother-tongue use, they argued, accounts for students framing what they want to say in their mother tongue and then translating into English, often resulting in mistakes. Another direct effect of multilingualism on students' acquisition of oral skills observed is that when they are assigned to perform a speaking task, they tend to think about the topic in their mother tongue (Ibid.). 


\section{Q.11 Do you teach pronunciation in your class?}

This question sought from participants whether they taught pronunciation as part of their Oral English lessons. Majority (31), representing $91 \%$ admitted teaching it, with only two $(6 \%)$ responding to the contrary. One participant did not respond to the question. Pronunciation constitutes a major component of the Oral English course and can also be one of the trickiest. Though it is heartwarming to observe that majority of the teachers said they taught pronunciation, it would be interesting to probe further to determine how effectively they are handling that aspect of the course.

Q12 Do you observe pronunciation problems among your students? And Q. 13 What do you observe to be the greatest problem of your students in pronunciation?

As to whether they observed any pronunciation challenges among their students, all the thirty-four survey participants $(100 \%)$ responded in the affirmative. They identified difficulty in articulating dental sounds. They observed that their students use $/ \mathrm{d} /$ for $/ \mathrm{d} / \mathrm{and} / \mathrm{t} /$ for $/ \theta /$. The students pronounce the word 'thank' $/ \theta æ \eta \mathrm{k} /$ as

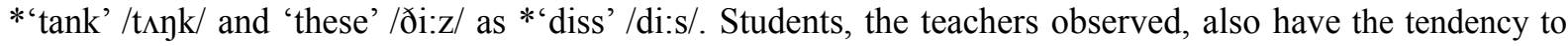
pronounce words as they see them written as the greatest challenges of their students. Each of the two problems was identified by eleven respondents, representing 32\% respectively. Mother-tongue interference followed in importance with five $(15 \%)$ of the respondents identifying it as a hindrance. Twelve percent of the participants also considered accent and intonation as major problems among their learners. One participant failed to respond to the question. The tendency of students pronouncing English words as they see them written is not surprising. As observed early in the literature review, English words are not spoken exactly as they are written; spelling of some words have little or no bearing at all on the way they are pronounced (Keli-Delataa, 2007). Unlike most of the local languages that the students speak, there is a high rate of incompatibility between English sounds and spelling.

Q.14 What do you think is the cause of the problem?

On the possible causes of the pronunciation problems among their students, majority (18) of the teachers representing 53\% identified mother-tongue (L1) interference as the most likely influencing factor. This finding affirms similar findings by earlier researchers like Aifuwa (2013) and Latha and Ramesh (2012) who observed in Nigeria and India respectively how L1 can be a major influencing factor in teaching English pronunciation in an ESL environment. Poor foundation at the junior high school level was cited by nine (27\%) of the participants as another possible cause of poor pronunciation of English words by students. Four of the respondents felt that the linguistic background of previous teachers of students could be a factor affecting the students' pronunciation. This finding also affirms the observation of Richards (2015) that poor quality teaching is a contributory factor to learner difficulty in acquiring good pronunciation skills in English. Difficulty or inability to read was also identified as a possible cause by two (6\%) of the respondents, a situation Richards (2015) ascribes to "lack of motivation" and "personal factors". One participant did not respond to this question.

Q.15 How can the pronunciation problem be handled?

As to how the problem of pronunciation among students could be addressed, 14 respondents constituting the majority $(41 \%)$ of the total population suggested that refresher courses be organised periodically for OE teachers. Six $(18 \%)$ of the teachers proposed the adoption of a practical approach to teaching the course; with four (12\%) recommending the teaching of phonetics at the SHS level. One respondent (3\%) suggested that the teaching of OE should start at the basic school level; while two (6\%) of the participants recommended the provision of quality TLMS for the teaching of the course in the SHSs. Seven participants $(21 \%)$ failed to respond to this question.

Q16 Do you have any suggestions on how to improve upon the teaching of Oral English?

On ways of improving upon the teaching of Oral English at the Senior High School, most (13) of the respondents representing $38 \%$ reiterated the need to introduce the teaching of phonetics at that level. Seven $(21 \%)$ of the respondents felt that a bit of encouragement to students could help remedy the situation. Organising regular or periodic training seminars for teachers of Oral English and engaging experts to teach the course at the JHS level received equal recommendation by four participants each, representing $12 \%$ respectively. One respondent declined to answer.

\subsection{Summary of Major Findings}

The data obtained from the survey were summarised in tables showing the number of respondents and relevant percentages (See Appendix A). From those summaries a number of interesting findings were made, five of which are: 
i. Majority of the teachers of Oral English in the Upper West region conceded they did not have any formal training in the relevant area to teach the course.

ii. Interestingly, all of them affirmed that they taught Oral English in their schools.

iii. Except in two cases, all the participating institutions had fairly large class sizes (40 or more students per class), which makes effective one-on-one interaction between the teacher and students difficult.

iv. Pronunciation constituted a major handicap for most students; a situation ascribed mainly to mother-tongue influence.

v. The teaching of Oral English and phonetics should start from the basic and JHS levels and be done by professionals trained for the purpose.

\section{Conclusion and Recommendations}

The aim of this study was to identify the challenges confronting teachers and learners of Oral English in Senior High Schools in the Upper West Region of Ghana and based upon its findings, suggest ways of addressing such challenges. Teachers of English from 34 SHSs from the region served as the sample population. Their responses to questionnaires used in a survey constituted the bulk of the primary data for this study, and to a lesser extent, the researcher's own observation. The researcher also consulted library materials like textbooks, journals and the internet. The data collected from the respondents were put into tables illustrating the number of respondents and percentages. From the summaries thus obtained, it was observed that:

Majority of the teachers of Oral English in the Upper West region did not have any formal training in the relevant area to teach the course. Pronunciation constituted a major handicap for most students in the area as a result mother-tongue interference, lack of relevant teaching and learning materials and large class sizes. Overall the study found that influence of mother-tongue on oral communication skills of students and the lack of relevant expertise and resources to teach the course effectively posed the major challenges.

\subsection{Recommendations}

As to how the problem of pronunciation among students could be addressed, it is recommended that

1) The teaching of Phonetics should start from the basic school level and should be handled by experts recruited purposely for that. At the SHS, phonetics should be taught as part of Oral English course.

2) To avoid learner apathy and enhance students' oral communication skills, it is suggested that students be encouraged to take reading seriously.

3) As a way of enhancing the skills of teachers of the course, it is recommended that regular or periodic seminars and refresher courses organised for subject teachers. As most of the schools in the region rely on untrained teachers to determine how to teach the syllabus, it is advisable that they are given a detailed syllabus with lessons, exercises and quizzes. The course could be designed by one or two experts who have detailed knowledge of the pedagogy, and then the teachers can implement it, modifying or enhancing it if need be. Alternatively, a very good basic course could be designed for adoption.

4) The provision of quality teaching and learning materials and language laboratory facilities can also contribute greatly to enhancing the teaching and learning of the Oral English course in SHSs.

5) For these suggestions to receive the necessary push, there is need for the appropriate authorities in government, the Ghana Education Service and the relevant subject teacher association, i.e. GATE, to come out with a clear-cut policy on Oral English education.

As observed from the literature review, the ability to express oneself fluently and correctly in the English language is the key to accessing the numerous opportunities available in education, business and commerce, politics and diplomacy and a lot more. Taking the teaching of the Oral English course a bit more serious by implementing the recommendations would go a long way to enhance the oral communication skills of our graduates and make them more competitive on the job market.

\section{References}

Aifuwa, O. B. (2013). The Problem of Teaching Oral English in Secondary Schools: A Case Study of Uvwie Local Government Area of Delta State. A Dissertation Submitted to the Department of English and Literary Studies, Delta State University, Abraka. 
Asare, C. (1999). Oral English now Compulsory for Final year SSS Students. General News, Monday, 31 May, 1999. Retrieved from www.ghanaweb.com/GhanaHomePage/News

Brown, H. D. (2007). Principles of Language Learning and Teaching (5th ed.). New York: Pearson Longman.

Chen, Z., \& Goh, C. (2011). Teaching Oral English in Higher Education: Challenges to EFL Teachers. Retrieved from

https://www.researchgate.net/publication/233056959_Teaching_oral_English_in_higher_education_challen ges_to_EFL_teachers

Crystal, D. (1990). The English Language. London: Penguin Books.

Daily Guide (2018). "WASSCE Candidates Fail Maths and English". Monday, 16 ${ }^{\text {th }}$ March, 2018 Edition. Retrieved from http://dailyguideafrica.com/wassce-candidates-fail-maths-english/ Accessed on: 22/09/18.

Delataa-Keli, K. (2007). Oral English for Senior High Schools. Millennium Edition. Accra: Aki-Ola Publications

Diep, L. T. N. (2017). Measurement of Factors Affecting English Speaking Skills of Students at the Foreign Language Department of Van Lang University. Research and Science Today, 1(13).

Ethnologue. (2017). Languages of the World: Ghana. Retrieved from https://ethnologue.com/country/GH

Gimson, A. C. (1980). An Introduction to the Pronunciation of English. London: Edward Arnold.

Kachru, B. B. (1986). The Alchemy of English: The Spread Functions and models of Non-native Englishes. Oxford: Pergamon.

Latha, B. M., \& Ramesh, P. (2012). Teaching English as a Second Language. Factors Affecting Learning Speaking Skills. International Journal of Engineering Research and Technology, 1(7).

Ministry of Education. (2010). Teaching Syllabus for English Language (Senior High School 1-3). Accra: Curriculum Development and Research Division.

Nordlund, E. (2004). Oral Communication in English Classes at Senior High School. Lulea: University of Technology.

Nunan, D. (1989). Designing Tasks for the Communicative Classroom. Cambridge: Cambridge University Press.

Richards, J. C. (2015). Reasons for Poor Speaking Skills. Retrieved from $\mathrm{http}$ ://www.professorjackrichards.com/reasons-for-poor-speaking-skills/

Richards, J. C., \& Renandya, W. A. (2002). Methodology in Language Teaching: An Anthology of Current Practice (pp. 254-266). Cambridge: Cambridge University Press. https://doi.org/10.1017/CBO9780511667190

Robinson, P. (1991). ESP Today: A Practitioner's Guide. London: Prentice Hall.

Taylor and Francis Online. (2011). Teaching in Higher Education. Retrieved from www.tandfonline.com

Ufomata, T. (1995). Setting Priorities in the Teaching English Pronunciation in ESL Contexts. Benin: Department of Phonetics and Literature, University of Benin, Nigeria.

Wellman, L. (1978). Teacher of English as a Second Language. New York: Acro Publishing Company Inc.

Wilkins, D. A. (1982). Second-Language Learning and Teaching. Great Britain: Richard Clay.

\section{Appendix A}

Tables Showing Summaries of Responses in Percentages (\%)

Table 1. Gender of participants

Source: Field Survey, 2016.

\begin{tabular}{ccc}
\hline & Frequency & Percent \\
\hline Male & 26 & 76.5 \\
Female & 8 & 23.5 \\
Total & 34 & 100.0 \\
\hline
\end{tabular}


Table 2. Area of study at the University

\begin{tabular}{ccc}
\hline & Frequency & Percent \\
\hline English & 16 & 47.1 \\
Dagaare & 8 & 23.5 \\
Other Language & 8 & 23.5 \\
Other Course & 2 & 5.9 \\
Total & 34 & 100.0 \\
\hline
\end{tabular}

Source: Field Survey, 2016.

Table 3. Highest qualification

\begin{tabular}{ccc}
\hline & Frequency & Percent \\
\hline BA & 20 & 58.8 \\
BSc & 12 & 35.3 \\
MA/MPhil & 2 & 3.9 \\
Total & 34 & 100.0 \\
\hline
\end{tabular}

Source: Field Survey, 2016.

Table 4. Age of respondents

\begin{tabular}{ccc}
\hline & Frequency & Percent \\
\hline $26-30$ & 4 & 11.8 \\
$31-35$ & 16 & 47.1 \\
$36 \&$ above & 14 & 41.2 \\
Total & 34 & 100.0 \\
\hline
\end{tabular}

Source: Field Survey, 2016.

Table 5. How long have you been teaching oral English?

\begin{tabular}{ccc}
\hline & Frequency & Percent \\
\hline $1-3 y r s$ & 12 & 35.2 \\
$4-6 y r s$ & 13 & 38.2 \\
$7-10 y r s$ & 1 & 2.9 \\
11 yrs \& Above & 7 & 20.6 \\
No resp. & 1 & 2.9 \\
Total & 34 & 100.0 \\
\hline
\end{tabular}

Source: Field Survey, 2016.

Table 6. Do you have formal training in oral English teaching?

\begin{tabular}{ccc}
\hline & Frequency & Percent \\
\hline Yes & 15 & 44.1 \\
No & 19 & 55.9 \\
Total & 34 & 100.0 \\
\hline
\end{tabular}

Source: Field Survey, 2016.

Table 7. Which classes do you teach?

\begin{tabular}{ccc}
\hline & Frequency & Percent \\
\hline SHS 1-3 & 7 & 20.6 \\
SHS 3 & 27 & 79.4 \\
Total & 34 & 100.0 \\
\hline
\end{tabular}

Source: Field Survey, 2016. 
Table 8 . What is the number on roll of the classes you teach?

\begin{tabular}{ccc}
\hline & Frequency & Percent \\
\hline $10-19$ & 1 & 2.9 \\
$20-29$ & 1 & 2.9 \\
30 and Above & 30 & 88.2 \\
Total & 34 & 100.0 \\
\hline
\end{tabular}

Source: Field Survey, 2016.

Table 9. Does any of your students have English as their L1?

\begin{tabular}{ccc}
\hline & Frequency & Percent \\
\hline Yes & 2 & 5.9 \\
No & 32 & 94.1 \\
Total & 34 & 100.0 \\
\hline
\end{tabular}

Table 10. Do you teach pronunciation in class?

\begin{tabular}{ccc}
\hline & Frequency & Percent \\
\hline Yes & 31 & 91.2 \\
No & 2 & 5.9 \\
No Response & 1 & 2.9 \\
Total & 34 & 100.0 \\
\hline
\end{tabular}

Source: Field Survey, 2016.

Table 11. Do you observe any pronunciation problems among learners?

\begin{tabular}{ccc}
\hline & Frequency & Percent \\
\hline Yes & 34 & 34 \\
No & 0 & 0 \\
Total & 34 & 100.0 \\
\hline
\end{tabular}

Source: Field Survey, 2016.

Table 12. What do you observe as the greatest problem of learners?

\begin{tabular}{lll}
\hline & Frequency & Percent \\
\hline 1. Articulating dental sounds & 11 & 32.4 \\
2. Accent \& Intonation & 4 & 11.8 \\
3. L1 interference & 5 & 14.7 \\
4. Poor foundation & 1 & 2.9 \\
5. Direct pronunciation & 11 & 32.4 \\
6. No response & 2 & 5.9 \\
Total & 34 & 100 \\
\hline
\end{tabular}

Source: Field Survey, 2016.

Table 13. What do you consider to be the causes of the problem?

\begin{tabular}{lll}
\hline & Frequency & Percent \\
\hline 1. L1 interference & 18 & 52.9 \\
2. Poor foundation at JHS & 9 & 26.5 \\
3. Inability to read & 2 & 5.9 \\
4. Linguistic background of previous teachers & 4 & 11.8 \\
5. No response & 1 & 2.9 \\
Total & 34 & 100 \\
\hline
\end{tabular}

Source: Field Survey, 2016. 
Table 14. How do you think the pronunciation problem can be handled?

\begin{tabular}{lll}
\hline & Frequency & Percent \\
\hline 1. Teach phonetics & 4 & 11.8 \\
2. Adopt practical approach & 6 & 17.6 \\
3. Introduce OE at Basic Sch. Level & 1 & 2.9 \\
4. Organise refresher courses for OE teachers & 14 & 41.2 \\
5. Provide Quality TLMS & 2 & 5.9 \\
6. No response & 7 & 20.6 \\
Total & 34 & 100.0 \\
\hline
\end{tabular}

Source: Field Survey, 2016.

Table 15. Do you have any suggestions on how OE teaching can be improved?

\begin{tabular}{lll}
\hline & Frequency & Percent \\
\hline 1. Teach Phonetics & 13 & 38.2 \\
2. Encourage constant reading & 7 & 20.6 \\
3. Regular training of teachers & 4 & 11.8 \\
4. Recruitment of professionals to teach OE at the basic level & 4 & 11.8 \\
5. No response & 2 & 5.9 \\
Total & 34 & 100.0 \\
\hline
\end{tabular}

Source: Field Survey, 2016.

\section{Copyrights}

Copyright for this article is retained by the author, with first publication rights granted to the journal.

This is an open-access article distributed under the terms and conditions of the Creative Commons Attribution license (http://creativecommons.org/licenses/by/4.0/). 